\title{
UPPER CRETACEOUS VOLCANOCLASTIC DEPOSITS FROM THE HAŢEG BASIN, SOUTH CARPATHIANS (ROMANIA): K-Ar AGES AND INTRABASINAL CORRELATION
}

\author{
ANA-VOICA BOJAR ${ }^{1,3}$, STANISLAW HALAS ${ }^{2}$, HANS-PETER BOJAR ${ }^{3}$, \\ DAN GRIGORESCU ${ }^{4}$ and STEFAN VASILE \\ ${ }^{I}$ Department of Geology, Salzburg University, Heillbrunnerstrasse 34, A-5020, Salzburg, Austria, \\ ${ }^{2}$ Mass Spectrometry Laboratory, Institute of Physics, 20-031 Lublin, Poland, \\ ${ }^{3}$ Department of Mineralogy, Weinzöttlstrasse 16, A-8045, Studienzentrum Naturkunde, Universalmuseum Joanneum, Graz, Austria \\ ${ }^{4}$ Department of Geology and Paleontology, University of Bucharest, Bd. N. Bălcescu 1, RO-010041 Bucharest, Romania
}

Received 4 October $2010 \quad$ Accepted 10 February 2011

\begin{abstract}
In order to constrain the age of the Upper Cretaceous continental Densuş-Ciula Formation from the Haţeg basin, South Carpathians, and correlate it with the other continental unit that occurs in the region, the Sânpetru Formation, we separated and dated by the K-Ar method biotites and amphiboles from volcanoclastic deposits. The mineral phases analysed are from two tuff layers and volcanic bombs cropping out near Rachitova village. Two tuff layers from the Densuş-Ciula Formation give early Maastrichtian ages of $69.8 \pm 1.3$ and $71.3 \pm 1.6 \mathrm{Ma}$, respectively. The ages determined for the tuff layers constrain the age of deposition for the Densuş-Ciula Formation and enable further correlations with the available palaeomagnetic data from the deposits occurring along the Sibişel Valley that belong to the Sânpetru Formation. The volcanic bombs collected near to Răchitova village are andesites and dacites. The age determined by K-Ar method on hornblende separated from a volcanic bomb is 82.7 $\pm 1.5 \mathrm{Ma}$, which is older than the underlying Campanian marine deposits in turbidite facies. This suggests that the volcanic bombs were re-deposited during the early Maastrichtian. Thus, the volcanics found at Răchitova have at least two origins: one type is related to an explosive synsedimentary volcanic activity, and the other type is represented by older andesitic/dacitic bombs, which most probably originate from a volcanic centre situated in the Haţeg region.
\end{abstract}

Keywords: volcanoclastics, continental deposits, radiometric dating, Campanian-Maastrichtian, Haţeg Basin, South Carpathians.

\section{INTRODUCTION}

The South Carpathians extend from the Prahova Valley in Romania to the Timoc Valley in Serbia. The mountain chain is bordered by the foreland sediments of the Moesian Platform to the south and the Transylvanian Depression to the north. During the Late Cretaceous time, sedimentation continued at the top of the upper plate along the Carpathians, Apuseni and Eastern Alps in the so-called "Gosau type" basins, which had been formed as a result of syncollisional extension (Lupu and Lupu, 1983; Wagreich and Faupl, 1994; Willingshofer, 2000). The facies association of these deposits may vary from terrestrial alluvial to turbiditic sediments stratigraphically spanning the Upper Turonian to the Maastrichtian.

Corresponding author: A. V. Bojar

e-mail: ana-voica.bojar@sbg.ac.at 
During the Late Cretaceous, an intrusive magmatism occurs in the South Carpathians and Apuseni. For this phase, only large intrusive bodies are known, but not in situ volcanic rocks (Grünfelder et al., 1983; Andrei et al., 1989, Berza et al., 1998; Ciobanu et al., 2002; Zimmerman et al., 2008). In the Poiana Rusca and the Haţeg basin, volcano-sedimentary deposits containing Upper Cretaceous volcanoclasts were also described (Anastasiu and Csobuka, 1989).

In the Haţeg basin, two different continental Formations of Maastrichtian age occur: the Densuş-Ciula and the Sânpetru Formations (Fig. 1). The Maastrichtian age of the middle Densuş-Ciula member and the Sânpetru Formation is constrained by freshwater gastropod assemblages and palinology (Antonescu et al., 1983; Stilla, 1985; Grigorescu et al., 1990; Grigorescu, 2010). In addition, the age base on calcareous nannofossils, of the youngest Cretaceous marine deposits that are overlaid by the Densuş-Ciula and, respectively Sânpetru Formations, is Late Campanian-Early Maastrichtian (Grigorescu and Melinte, 2001; Melinte-Dobrinescu, 2010). Palaeomagnetic studies were carried out for the Sibişel Formation. For the Densuş-Ciula Formation, the palaeomagnetic signal displays no consistent results (Panaiotu and Panaiotu, 2010). Bojar et al. (2010a) found high amounts of magnetic titanohematite (up to $40 \%$ ) with tabular crystallographic forms in the heavy mineral fraction of the Densuş-Ciula Formation, which disturbed the primary magnetic signal. The preservation of this mineral, which is most probably of volcanic origin, was favoured by the general dry and oxic conditions at the time of deposition. For the Haţeg basin, the seasonally dry to sub-humid conditions prevailed during the sedimentation of DensuşCiula Formation (for example, Tuştea outcrop), with the deposits occurring along Bărbat Valley (up-stream to Pui village, $45^{\circ} 30^{\prime} 4 " 23^{\circ} 05^{\prime \prime E}$ ) and the lower part of the deposits occurring in the Sibişel Valley (upstream to Sânpetru village, $45^{\circ} 32^{\prime} 4^{\prime \prime N} 22^{\circ} 54^{\prime} 3 " \mathrm{E}$ ). These conditions were put in evidence by mineralogical and isotopic investigations of palaeosol and fossil remains (Bojar et al., 2005; Bojar et al., 2009; Bojar et al., 2010b). Recent palinological investigations (Lindfors et al., 2010) from a site situated near Vălioara, in the Densuş-Ciula Formation (Fig. 1), also support seasonally dry conditions during the formation of the deposits.
In order to constrain the age of the Densuş-Ciula Formation and correlate it with the Sânpetru Formation, we separated and dated by the K-Ar method biotites and amphiboles from the volcanoclastic deposits. The mineralogy and lithology of the samples were done using X-ray diffraction and semi-quantitative determinations. Further correlations and interpretations are based on the new data presented in this study and previously published palaeomagnetic and biostratigraphy.

\section{ANALYTICAL DATA}

\section{Mineralogical composition of the samples}

The collected rock samples were crushed, sieved, washed and dried at $50^{\circ} \mathrm{C}$. The different minerals were than separated using sodium polytungstate solution and by hand picking under binocular. The mineralogy of single grains was also checked/determined using an X-ray diffractometer. Both heavy mineral concentrates $(\rho>2.9$ $\mathrm{r} / \mathrm{cm}^{3}$ ) and the light fraction were analysed using a Bruker AXS powder diffractometer with a Lynx Eye detector (Cu-k $, 40 \mathrm{kV}, 40 \mathrm{~mA}, 0.02^{\circ}$ step size, 2 seconds/step). The diagrams were compared with the ICDD PDF4 database. The results of the analyses are given in Table 1. A semi-quantitative estimation of the modal quartz-alkali feldspar-plagioclase composition of the light fraction $\left(\rho<2.9 \mathrm{r} / \mathrm{cm}^{3}\right.$, fraction $\left.425-850 \mu \mathrm{m}\right)$ of crushed volcanic bombs was done using the RIR-method (reference intensity ratio) (Chung, 1974a, 1974b; Chung, 1975). A representative amount of the sieve fraction was chosen and ground in an agate mortar. The resulting powder was mounted with ethanol on a Si-low background sample holder.

\section{K/Ar data}

Only mineral concentrates were dated in this study. The $\mathrm{K}$ contents were determined by thermal isotope mass spectrometry (TIMS) using the isotope dilution technique, as described by Hałas (2001). Radiogenic argon concentration $\left({ }^{40} \mathrm{Ar} *\right)$ was determined on the instrumental set-up of the Mass Spectrometry Laboratory described in detail by Durakiewicz (1995). The analytical results are presented in Table 2 . The overall standard uncertainty (given in Table 2) resulting from uncertainties of $\mathrm{K}$ and

Table 1. Mineralogical composition of the light and heavy mineral concentrates $\left(\rho>2.9 \mathrm{~g} / \mathrm{cm}^{3}\right)$ of volcanic bombs obtained by powder XRD. The number gives a semi-quantitative estimation of the modal mineralogical composition. QAP: quartz - alkali feldspar - plagioclase.

\begin{tabular}{lll}
\hline Sample & Heavy fraction & QAP Light fraction \\
\hline RA-1 bomb, andesite & amphibole (63), clinopyroxene (37) & Q (10), A (11), P (79) \\
\hline RA-2 bomb, andesite & amphibole (18), clinopyroxene (72) & Q (2), A (2), P (96) \\
\hline RA-6 bomb, andesite & amphibole (82), clinopyroxene (28) & Q(n.d.), A (2), P(98) \\
\hline RA-7 bomb, dacite & amphibole (28), clinopyroxene (46), hematite (26) & Q (32), A (n.d.), P (68) \\
\hline RA-8, andesite & clinopyroxene (98), hematite (2) & Q (2), A (5), P (93) \\
\hline RA-12, andesite & biotite & Q (n.d.), A (4), P (96) \\
\hline RA-14, andesite & clinopyroxene (94), hematite (6) & Q (18), A(4), P (78) \\
\hline
\end{tabular}



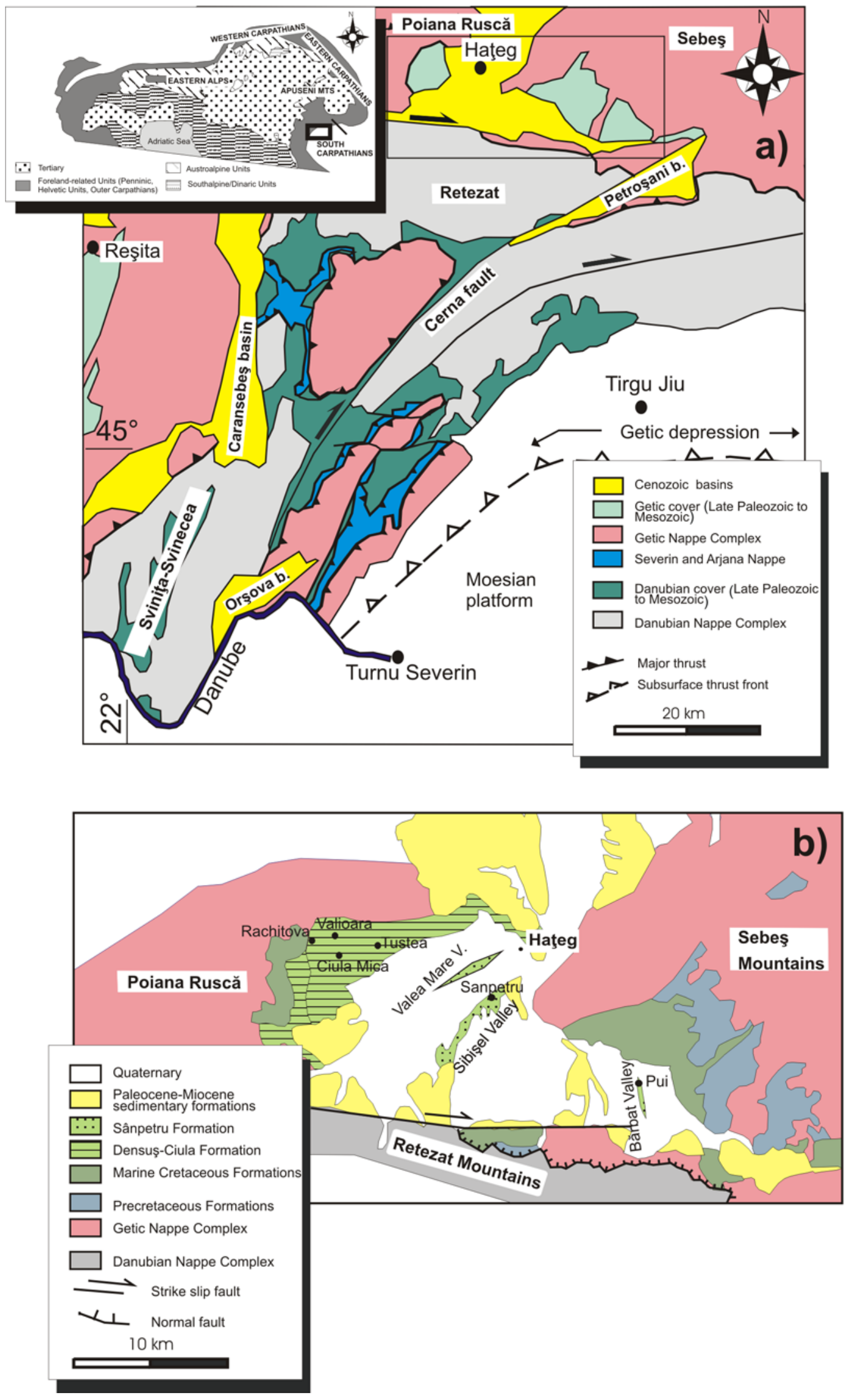

Fig. 1. Geological map showing the Răchitova and Vălioara locations. 
${ }^{40} \mathrm{Ar} *$ determinations was calculated by the error propagation formula derived by Cox and Dalrymple (1967).

\section{RESULTS}

The Densuş-Ciula Formation crops out in the northwestern and central part of the basin and is divided into three members (Grigorescu et al., 1990). The Lower Member of the Densuş-Ciula Formation contains lacustrine marls with volcanoclastics. The Middle Member of the Densuş-Ciula Formation comprises matrix-supported conglomerates, cross-bedded sandstones and massive red mudstones (Bojar et al., 2005; Grigorescu et al., 2010). The smectite rich palaeosols at Tuştea (also situated in the middle Densuş-Ciula Member) indicate that volcanic glass material contributed to sedimentation, but was altered to Ca-Na smectites (Bojar et al., 2009).

The Răchitova outcrop $\left(45^{\circ} 36^{\prime} 5^{\prime \prime} \mathrm{N} ; 22^{\circ} 45^{\prime} 5^{\prime \prime} \mathrm{E}\right)$ is situated in the NW part of the basin, in the lower DensuşCiula member. Volcanoclastic deposits lie discordantly on the uppermost Campanian flysch deposits, and the contact between the marine and the continental formation is erosive (Grigorescu and Melinte, 2001). In Fig. 2, the previously published lithological column (Barzoi and

Table 2. KAr data of the examined samples.

\begin{tabular}{|c|c|c|c|c|c|}
\hline Sample & Phase & $\mathrm{K}(\%)$ & ${ }^{40} \mathrm{Ar}^{*}(\mathrm{pmol} / \mathrm{g})$ & ${ }^{40} \mathrm{Ar}^{*}(\%)$ & Age $\pm 1 \sigma(\mathrm{Ma})$ \\
\hline$\overline{R A-1, ~ R a ̆ c h i t o v a ~ v o l c a n i c ~ b o m b ~}$ & amphibole & 1.11 & 163.1 & 80.2 & $82.7 \pm 1.5$ \\
\hline RA-12, Răchitova tuff layer & biotite & 3.04 & 375.3 & 68.5 & $69.8 \pm 1.3$ \\
\hline AVROM-204, Geat Valley tuff layer & biotite & 5.70 & 718.4 & 52.6 & $71.3 \pm 1.6$ \\
\hline
\end{tabular}

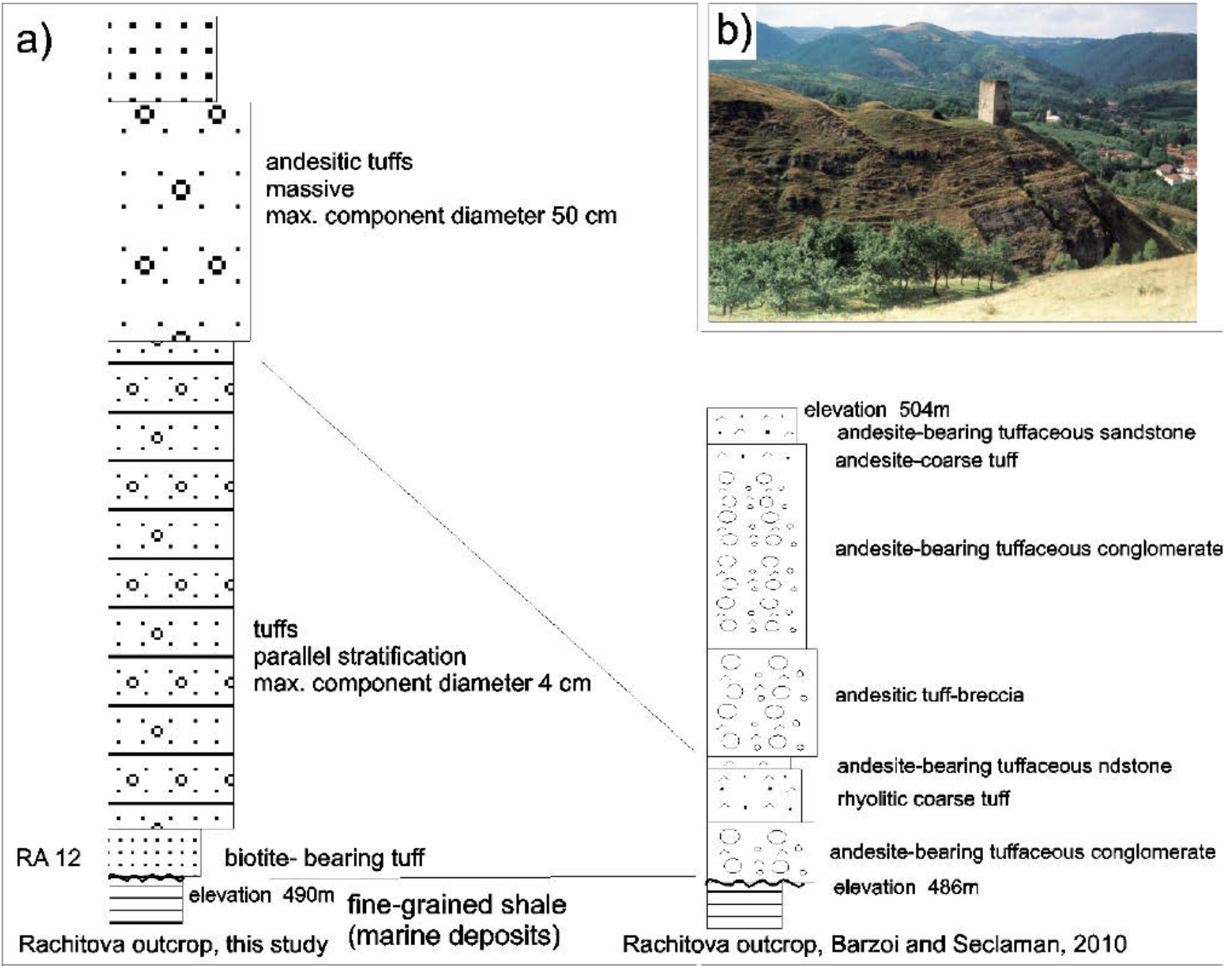

Fig. 2. a) Lithology of the outcrop; b) Răchitova outcrop with the medieval watching tower on top. 
Seclaman, 2010) is correlated with the lithological column, on which we plotted the position of the collected sample analysed in this study. Despite lateral variations of lithology, several major sequences may be identified. The mineralogy of all the collected bombs is plotted in the well-known QAPF diagram of Streckeisen (1964) modified by Le Maitre et al. (2004) (see Fig. 3). The quantitative results are only estimations because the albite content is attributed to plagioclase. According to the definitions of Streckeisen (1964 \& 1976), albite has an anorthite component smaller than 5\% $\left(\mathrm{An}_{05}\right)$. Barzoi and Seclaman (2010) give a table and a figure with feldspar analyses of volcanic bombs from Răchitova. Ca-Na feldspars are mainly plagioclase, with a predominant $\mathrm{An}_{50}$ composition. According to the classification of Le Maitre et al. (2004), most of the volcanic bombs that we collected at Răchitova are andesite/basalt, one sample plots in the dacite field. These results are in good accordance with Barzoi and Seclaman (2010). Heavy mineral concentrates of the volcanic bombs were analysed with powder-XRD as well. Amphibole and clinopyroxene are the dominant minerals in the heavy mineral spectra. In one sample, hematite is a major component as well.

For biotites concentrates from a tuff layer situated at the base of the continental section, an early Maastrichtian age of $69.8 \pm 1.3 \mathrm{Ma}$ was obtained. This corresponds to the fact that the continental volcanoclastic deposits lie discordantly on the Campanian flysch situated below. One volcanic bomb, RA-1, shows an age of $82.7 \pm 1.5$ Ma older than the underlying Campanian flysch.

I then Geat valley $\left(45^{\circ} 36^{\prime} 37^{\prime \prime} \mathrm{N} ; 22^{\circ} 46^{\prime} 22^{\prime \prime} \mathrm{E}\right)$, near Ciula Mica red paleosols occur. These paleosols are similar to those described at Tuştea (Bojar et al., 2005). In this paleosols, a white, c. 40-cm-thick clay layer is inter-

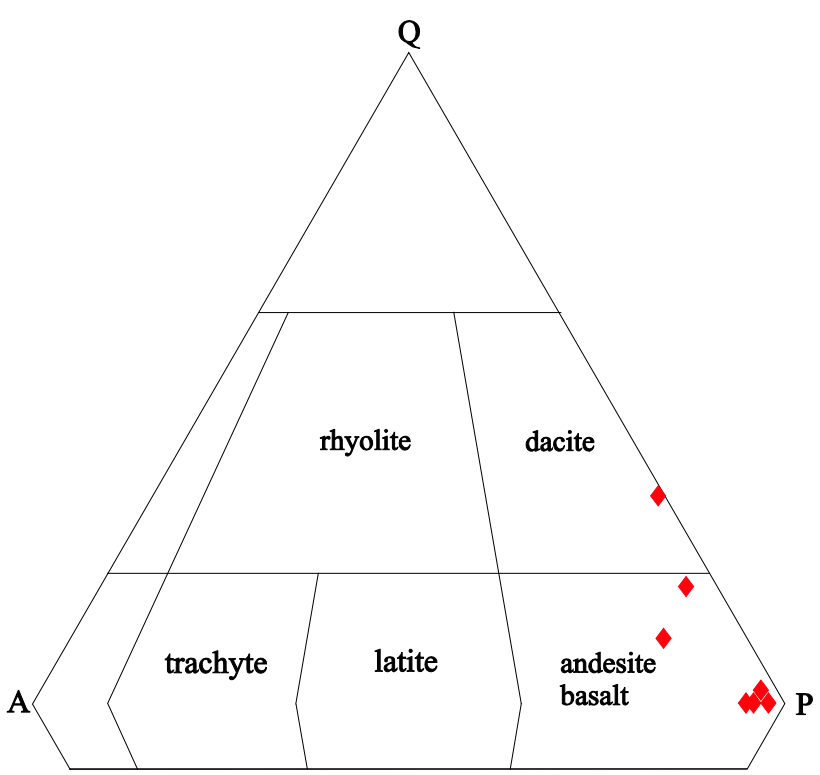

Fig. 3. Streckeisen diagramm (after Le Maitre et al., 2004) showing the lithology of the volcanic bombs. calated. Within the smectite matrix, quartz, zoned plagioclase, sanidine, and biotite crystals were found, indicating that the white layer corresponds to an altered tuff. The KAr dating of biotites separated from this sample, AVROM-204, gives an early Maastrichtian age of $71.3 \pm 1.6 \mathrm{Ma}$.

\section{DISCUSSION AND CONCLUSIONS}

The K-Ar dating of unaltered biotites from two tuff layers, one of which is found at the base of the DensuşCiula Formation, while the other is situated eastward within this Formation, give ages of $71.3 \pm 1.6$ and $69.8 \pm 1.3 \mathrm{Ma}$, respectively. Between the two outcrops, there is no clear stratigraphical correlation in the field, a fact related to restricted availability of outcrops. As for the continental deposits, the transport direction of sediments is generally north-south (see Bojar et al., 2010a and references therein). It is probable that the present northern part of the basin was filled by several almost coeval alluvial fans with similar, but not identical source areas. The volcanic bombs analysed show ages older than the stratigraphic age of the deposits and the Campanian marine deposits in turbidite facies underlying the volcanoclastics at Răchitova. This fact indicates that at least part of the volcanic bombs at this site were eroded and redeposited.

Palaeomagnetic studies (Panaiotu and Panaiotu, 2010) demonstrate that the continental sequence along the Sibişel valley (Sânpetru Formation, southern-central part of the basin) was deposited between the chron 32n.1 and the end of the chron $31 \mathrm{n}$. The Haţeg basin was situated at that time between 22.6 and $28.5^{\circ} \mathrm{N}$ (Panaiotu and Panaiotu, 2010). The outcrop showing deposition during the chron 32n.1 is situated upstream of the Sânpetru village. In this study, the geomagnetic polarity correlates to stratigraphic stages, according to Bralower et al. (1995), Burnett (1998), Lewy and Odin (2001), Melinte and Odin (2001). The stage's boundaries were defined by Scott (2009). Using the correlation between palaeomagnetic chrons and absolute ages, the sequence along the Sibişel valley was deposited between approx. 72 to $67.8 \mathrm{Ma}$. Thus, the deposits at the base of the sequence that occur along Sibișel Valley (the reddish member) have a similar lower Maastrichtian age to the deposits at Răchitova and Valea lui Geat.

The age of the Late Cretaceous mineralization related to intrusive magmatism in the South Carpathians was determined by applying the Re-Os method to molibdenites. The ages range between $72 \mathrm{Ma}$ for Moldova Noua pluton to $80 \mathrm{Ma}$ for Baita Bihor (in the Apuseni Mountains), and even 85.7 Ma for Ciclova (Ciobanu et al., 2002; Zimmerman et al., 2008). The K-Ar ages on mineral phases presented in this study have a similar range and represent the only radiometric determination for the Late Cretaceous effusive rocks available to date. According to this study, the volcanoclasts found at Răchitova 


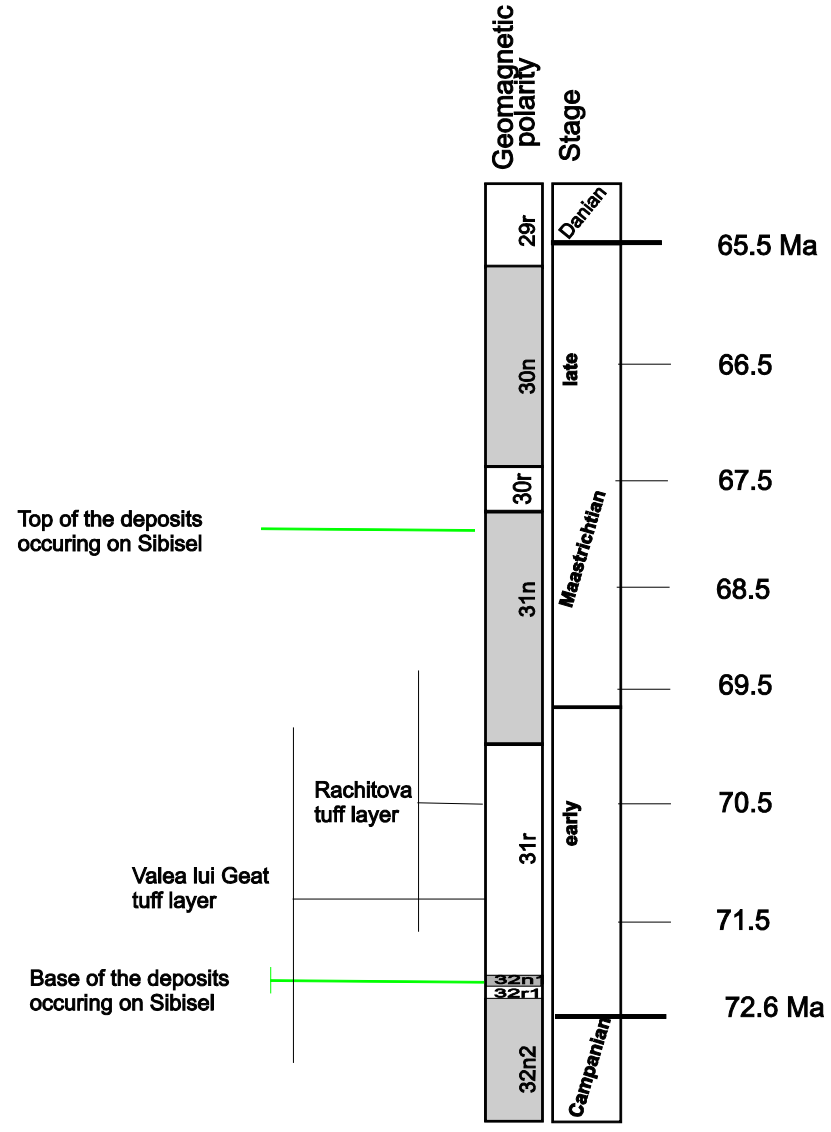

Fig. 4. Age constrains and correlations for the two Formations, Densuş Ciula and Sânpetru.

have two origins: one type is related to a synsedimentary volcanic activity (zeolitized tuff layers at the base of Răchitova or clay rich tuffs near Vălioara), and the other type is older and re-deposited from a volcanic centre situated near Haţeg. As most of the volcanic bombs are altered, it is difficult to assess the distribution of ages by $\mathrm{K}-\mathrm{Ar}$ method. The high proportion of smectite and titanohemtite found in several outcrops from the northern and central part of the basin is also related to volcanic activity during the early Maastrichtian. It is not possible to determine if, for example, the titanomagnetite was deposited during the early Maastrichtian explosive phase directly and/or was previously deposited around a volcanic centre, eroded and re-deposited at the time of early Maastrichtian.

\section{ACKNOWLEDGEMENTS}

We acknowledge a constructive review by Mihalea Melinte-Dobrinescu (Geoecomar, Bucharest) and an anonymous reviewer. This work was funded by a MOEL Grant of the Österreichische Forschungsgemeinschaft to Ana-Voica Bojar. For field trip support, Stefan Vasile acknowledges CNCSIS Grant 1930/2009.

\section{REFERENCES}

Anastasiu N and Csobuka D, 1989. Non-marine uppermost Cretceous deposits from the Stei-Densuş Region (Haţeg Basin): sketch for a facies model. Revue de Geologie Academia Romana 35: 45-53.

Andrei I, Cristescu T, Calotă C, Proca A, Romanescu D, RussoSăndulescu D, Ştefan A, Suceavă M, Bradu M, Hannich D and Alboiu M, 1989. Spatial distribution and structural images of banatites from Romania, deduced from gravity and magnetic data. Revue Roumaine de Géologie, Géophysique et Géographie - Série de Géophysique 33: 79-85.

Antonescu E, Lupu D and Lupu M, 1983. Correlation palinologique du Crétacé terminal du sud-est des Monts Metaliferi et des Depressions de Hațeg et de Rusca Montană (Palinological correlation of the Upper Cretaceous from the south-east Metaliferi Mountains and Hateg basin). Annales de l'Institut de Géologie et Géophysique 59: 71-77 (in French).

Barzoi S and Seclaman M, 2010. Petrographic and geochemical interpretation of the Late Cretaceous volcaniclastic deposits from the Hațeg Basin. Palaeogeography, Palaeoclimatology, Palaeoecology 293(3-4): 306-318, DOI 10.1016/j.palaeo.2009.08.028.

Berza T, Constantinescu E and Vlad Ş-N, 1998. Upper Cretaceous Magamatic Series and Associated Mineralisation in the Carpathian-Balkan Orogen. Resource Geology 48(4): 291-306, DOI 10.1111/j.1751-3928.1998.tb00026.x.

Bojar A-V, Grigorescu D, Ottner F and Csiki Z, 2005. Paleoenvironmental interpretation of dinosaur- and mammal-bearing continental Maastrichtian deposits, Haţeg basin, Romania. Geological Quarterly 49: 205-222.

Bojar A-V, Ottner F, Bojar H-P, Grigorescu D, Persoiu A, 2009. Stable isotope and mineralogical investigations on clays from Late Cretaceous sequences, Hațeg Basin, Romania. Applied Clay Sciences 45(3): 155-163, DOI 10.1016/j.clay.2009.04.005.

Bojar A-V, Bojar H-P, Ottner F and Grigorescu D, 2010a. Heavy mineral distributions of Maastrichtian deposits from the Haţeg basin, South Carpathians: tectonic and palaeogeographic implications. Palaeogeography, Palaeoclimatology, Palaeoecology 293(3-4): 319-328, DOI 10.1016/j.palaeo.2009.10.002.

Bojar A-V, Csiki Z and Grigorescu D, 2010b. Stable isotope distribution in Maastrichtian vertebrates and paleosols from the Haţeg Basin, South Carpathians. Palaeogeography, Palaeoclimatology, $\begin{array}{lll}\text { Palaeoecology 293(3-4): } & 329-342, & \text { DOI }\end{array}$ 10.1016/j.palaeo.2009.08.027.

Bralower TJ, Leckie RM, Sliter WV and Thierstein HR, 1995. An integrated Cretaceous microfossil biostratigraphy. In: Berggren WA, Kent DV, Aubry M-P and Hardenbol J, eds., Geochronology, Time Scales, and Global Stratigraphic Correlation. SEPM, Special Publication 54: 65-79.

Burnett JA, 1998. Upper Cretaceous. In: Bown PR, ed., Calcareous Biostratigraphy. British Micropalaeontological Society, Publication Series: 132-199.

Ciobanu CL, Cook NJ and Stein H, 2002. Regional setting and geochronology of the Late Cretaceous Banatitic Magmatic and Metallogenetic Belt. Mineralium Deposita 37: 541-567.

Chung FR, 1974a. Quantitative Interpretation of X-ray Diffraction Patterns of Mixtures. I. Matrix-Flushing Method for Quantitative Multicomponent Analysis. Journal of Applied Crystallography 7(6): 519-525, DOI 10.1107/S0021889874010375.

Chung FR, 1974b. Quantitative Interpretation of X-ray Diffraction Patterns of Mixtures. II. Adiabatic Principle of X-ray Diffraction Analysis of Mixtures. Journal of Applied Crystallography 7(6): 526-531, DOI 10.1107/S0021889874010387.

Chung FR, 1975. Quantitative Interpretation of X-ray Diffraction Patterns of Mixtures. III. Simultaneous Determination of a Set of Reference Intensities. Journal of Applied Crystallography 8(1): 17-19, DOI 10.1107/S0021889875009454.

Cox A and Dalrymple GB, 1967. Statistical analysis of geomagnetic reversal data and the precision of potassium-argon dating. Journal of Geophysical Research 72: 2603-2614.

Durakiewicz T, 1995. Innowacje w aparaturze do wydzielania i oczyszczania argonu (Improvements in the argon extraction and 
purification line). In: Durakiewicz T, ed., Dating of Minerals and Rocks II. Wydawnictwo PTF Lublin: 44-52 (in Polish).

Grigorescu D, 2010. The Latest Cretaceous fauna with dinosaurs and mammals from the Hateg Basin - A historical overview. Palaeogeography, Palaeoclimatology, Palaeoecology 293(3-4): 271-282, DOI 10.1016/j.palaeo.2010.01.030.

Grigorescu D and Melinte M, 2001. The stratigraphy of the Upper Cretaceous marine sediments from the NW Haţeg area (South Carpathians, Romania). Acta Palaeontologica Romaniae 3: 153160.

Grigorescu D, Avram E, Pop G, Lipu M and Anastasiu N, 1990. Guide to excursion. International Symposium IGCP Projects 245: Nonmarine Cretaceous Correlation; Project 282: Tethyan Cretaceous Correlation, Bucharest: 109 pp.

Grigorescu D, Garcia G, Csiki, Z, Codrea V and Bojar A-V, 2010. Uppermost Cretaceous megaloolithid eggs from the Hațeg Basin, Romania, associated with hadrosaur hatchlings: Search for explanation. Palaeogeography, Palaeoclimatology, Palaeoecology 293(3-4): 360-374, DOI 10.1016/j.palaeo.2010.03.031.

Grünfelder M, Popescu G, Soroiu M, Arsenescu V and Berza T, 1983. $\mathrm{K}-\mathrm{Ar}$ and $\mathrm{U}-\mathrm{Pb}$ dating of the metamorphic Formations and the associated igneous bodies of the central South Carpathians. Annales de l'Institut de Géologie et Géophysique 61: 37-46.

Hałas S, 2001. Analiza pierwiastkowa techniką rozcieńczenia izotopowego na przykładzie określania zawartości potasu w minerałach datowanych metoda $\mathrm{K} / \mathrm{Ar}$ (Elemental analysis by isotope dilution technique on the example of $\% \mathrm{~K}$ determination in minerals to be dated by K/Ar method). Elektronika 42(8-9): 53-55 (in Polish).

Lewy Z and Odin GS, 2001. Magnetostratigraphy across the Campanian-Maastrichtian boundary at Tercis les Bains in comparison with northern Germany, the Apennines (Central Italy) and North America: biostratigraphical and geochronological constraints. In: Odin G, ed., The Campanian-Maastrichtian Stage Boundary; Characterisation at Tercis les Bains (France) and Correlation with Europe and Other Continents. Amsterdam, Elsevier Science BV: 175-183.

Le Maitre RW, Streckeisen A, Zanetti B, Le Bas MJ, Keller J, Lamayre J, Sabine PA, Schmid R, Sorensen H and Wooley AR, 2004. Igneous rocks: a classification and glossary of terms. Cambridge University Press, Cambridge, 236 pp.

Lindfors, SM, Csiki Z, Grigorescu D and Friis, EM, 2010. Preliminary account of plant mesofossils from the Maastrichtian Budurone microvertebrate site of the Haţeg Basin, Romania. Palaeogeography, Palaeoclimatology, Palaeoecology 293(3-4): 353-359, DOI 10.1016/j.palaeo.2009.10.018.

Lupu D and Lupu M, 1983. Biostratigraphische und fazielle Merkmale der "GosauFormation" im Apuseni Gebirge (Biostratigraphy and facies of the "Gosau Formation”, Apuseni Mountains). Anuarul Institutului de Geologie si Geofizică 59: 95-100 (in German).

Melinte MC and Odin G, 2001. Optical studies of the calcareous nannofossils from Tercis-les Bains (Landes, SW France) at the Campanian-Maastrichtian Boundary. In: Odin G, ed., The CampanianMaastrichtian Stage Boundary; Characterisation at Tercis les Bains (France) and Correlation with Europe and Other Continents. Amsterdam, Elsevier Science BV: 101-117.

Melinte-Dobrinescu, M.C., 2010. Lithology and biostratigraphy of Upper Cretaceous marine deposits from the Hateg region (Romania): palaeoenvironmental implications. Palaeogeography, Palaeoclimatology, Palaeoecology 293(3-4): 283-294, DOI 10.1016/j.palaeo.2009.04.001.

Panaiotu CG and Panaiotu CE, 2010. Palaeomagnetism of the Upper Cretaceous Sânpetru Formation (Haţeg Basin, South Carpathians). Palaeogeography, Palaeoclimatology, Palaeoecology 293(3-4): 343-352, DOI 10.1016/j.palaeo.2009.11.017.

Scott RW, 2009. Chronostratigraphic database for Upper Cretaceous oceanic red beds (CORBS). In: Hu X, Wang C, Scott RW, Wagreich $\mathrm{M}$ and Jansa L, eds., Cretaceous oceanic red beds: stratigraphy, composition, origins, and paleoceanographic and paleoclimatic significance. SEPM (Society for Sedimentary Geology) Special Publication 91: 35-57.

Stilla Al, 1985. Geologie de la region de Hațeg-Cioclovina-Pui-Bănița (Carpathes Meridionales) (Geology of the Haţeg-Cioclovina-PuiBănița). Annales de l'Institut de Géologie et Géophysique 66: 91179 (in French).

Streckeisen A, 1964. Die Klassifikation der Eruptivgesteine (The classification of volcanic rocks). Neues Jahrbuch für Mineralogie: 195222 (in German).

Streckeisen A, 1976. To each plutonic rock its proper name. Earth Science Reviews 12(1): 1-33, DOI 10.1016/0012-8252(76)900520 .

Wagreich M and Faupl P, 1994. Palaeogeography and geodynamic evolution of the Gosau Group of the Northern Calcareous Alps (Late Cretaceous, Eastern Alps, Austria). Palaeogeography, Palaeoclimatology, Palaeoecology 110(3-4): 235-254, DOI 10.1016/0031-0182(94)90086-8.

Willingshofer E, 2000. Extension in collisional orogenic belts: the Late Cretaceous evolution of the Alps and Carpathians. PhD Thesis, Vrije Universiteit, Amsterdam: $146 \mathrm{pp}$.

Zimmerman A., Stein HJ, Hannah JL, Koželj D, Bogdanov K, Berza T, 2008. Tectonic configuration of the Apuseni-Banat-TimokSrednogorie belt, Balkans-South Carpathians, constrained by high precision RE-OS molybdenite ages. Mineralium Deposita 43: 121. 